2. Ocherki istorii Penzenskoj organizacii KPSS. - Saratov: Privolzh. kn. izd-vo (Penzen. otd-nie), 1983.

3. Penzenskaja oblast' v cifrah i faktah. - Saratov: Privolzh. kn. izd-vo (Penzen. otd-nie), 1987.

4. Prokaev K. Pod vlijaniem idej bol'shevikov (Iz istorii ustanovlenija Sovetskoj vlasti v sjolah Gorodishhenskogo rajona) // Znamja truda. -- 1991. - 21 nojabrja.

5. Savin O.M. Lenin i Penzenskij kraj. - Saratov: Privolzh. kn. izd-vo (Penzen. otd-nie), 1980.

6. Stranicy bylogo/ Vospominanija uchastnikov revoljucionnyh sobytij 1917-1918 gg. v Penzenskoj gubernii/ Penza: Penzenskoe kn. izd-vo, 1957.

УДК 929 DOI: 10.24045/conf.2017.1.24

НОМО SOVETICUS: ОБЫКНОВЕННАЯ ИСТОРИЯ

\author{
Милаева О.В. \\ кандидат исторических наук, \\ дочент кафедры \\ «Философия и социиальные коммуникациии, \\ Пензенский государственный университет, \\ Пенза, Россия
}

Аннотация. Статья посвящена особенностям советского менталитета периода 1960-70-х годов. Автор сравнивает различные точки зрения на основные ценности и особенности поведения советского человека. В статье делается вывод, что hoто soveticus - это не единый антропологический тип в СССР, а идеальный набор значимых для развития общества и человека нравственных качеств, которые стали целью в сочииальном и ментальном пространстве советского общества.

Ключевые слова: homo soveticus, труд в СССР, инженерно-техническая интеллигенция, квалифицированные кадры, советский человек, коллективизм.

\title{
HOMO SOVETICUS: ORDINARY HISTORY
}

Milaeva O. V., Candidate Of historical sciences, Associate professor of «Philosophy and social communication» department Penza State University, Penza, Russian Federation

\begin{abstract}
The article is devoted to the peculiarities of the Soviet mentality of the period 1960-70 s. The author compares various views on the basic values and behaviors of Soviet man. The article concludes that homo soveticus is not a single anthropological type in the USSR, but an ideal set of moral qualities that are significant for the development of society and human, which have become a goal in the social and mental space of Soviet society.

Keywords: homo soveticus, labor in the USSR, Engineering and technical intelligentsia, skilled staff, Soviet person, collectivism.

История, воспринятая в человеческом измерении, - это всегда определённый образ человека эпохи, находящийся в неразрывной с ней связи, порождённый самой эпохой. Рыцарь без страха и упрёка, экзальтированный
\end{abstract}


монах, титаны Возрождения, славный мушкетёр, изнеженный аристократ XVIII века, утонченный денди, рафинированный интеллигент, пламенный революционер...

Октябрьская революция 1917 года - одно из крупнейших по масштабам исторических событий XX века - не могла не породить нового человека - homo soveticus. Однако новому обществу даже при необычайно высоких темпах индустриальных и социально-политических изменений для этого потребовалось не одно десятилетие.

Поэтому вызывают недоумение попытки увидеть прототип советского человека - и уже с отрицательной оценкой - в форме «homo socialisticus», в высказываниях С. Булгакова о революционных солдатах и матросах: «...Признаюсь вам, что «товарищи» кажутся мне иногда существами, вовсе лишёнными духа и обладающими только низшими душевными способностями, особой разновидностью дарвиновских обезьян - homo socialisticus» [3]. Цитата относится к 1918 году, когда ещё никакого нового советского человека быть не могло. Напротив, это результат воспитания в «России, которую мы потеряли», одновременно репрессивной политики по отношению к основной массе народа и православной духовности. Вспомним Блока: «Почему дырявят древний собор? - Потому что сто лет здесь ожиревший поп, икая, брал взятки и торговал водкой. Почему гадят в любезных сердцу барских усадьбах? - Потому, что там насиловали и пороли девок; не у того барина, так у соседа. Почему валят столетние парки? - Потому что сто лет под их развесистыми липами и клёнами господа показывали свою власть...» [2].

Но самой ходовой интерпретацией стало восприятие этого словосочетания через призму убийственней иронии. И этот термин - homo soveticus, введенный профессором-эмигрантом А. Зиновьевым, имевший презрительнонасмешливую окраску, прочно укоренился в социальной психологии как квинтэссенция негативного, порождённого в человеке советским строем [6]. Сам Александр Зиновьев родился в крестьянской семье. Переселившись в Москву, его отец работал маляром. При этом будущий диссидент не только получил при Советской власти образование и поступил в Московский институт философии, литературы и истории (ИФЛИ), а будучи из него исключённым (за антисталинские высказывания: о ужас! за антисталинские высказывания не репрессирован, не расстрелян в страшном 1939 году!), но и, воюя в ВОВ в штурмовой авиации, был награждён орденом Красной Звезды. После войны Зиновьев окончил МГУ и работал в Академии наук СССР, был заведующим кафедрой логики философского факультета МГУ. Как видим, путь этого homo soveticus (а так он и себя называет) - из крестьян в московские профессоры, - значительно отличается от подоплёки известного «мифа о бревенчатой хижине» Э. Пессена в сторону не мифа, а реальности.

И реальность эта была такова, что в «прекрасной» России прошлого (Российской империи) крестьянский сын, сменивший статус на сына чернорабочего, рассчитывать на такое развитие событий вряд ли смог бы. Напомним, что жизнь дореволюционного крестьянства (а это самый 
многочисленный слой, то есть непосредственно почти весь народ) оценивалась как суровая, жестокая и беспросветная. Вот, например, свидетельство В. Короленко: «Bы свежий человек, натыкаетесь на деревню с десятками тифозных больных, видите, как больная мать склоняется над кольбелью больного ребёнка, чтобы покормить его, теряет сознание и лежит над ним, а помочь некому, потому что муж на полу бормочет в бессвязном бреду. И вы приходите в ужас. А «старый служака» привык.... Тифр? Да ведь это у нас всегда! Лебеда? Да у нас этой каждый год!»

И речь ведь у авторов идет не о неординарном случае, а постоянном жестоком голоде в русской деревне. Для того чтобы получить хлеб, царское правительство принимало жёсткие конфискационные меры - экстренно увеличивало налоги в определённых районах, взыскивало недоимки, иногда просто изымало излишки силовым путём - полицейскими урядниками с отрядами казаков (как видим, продналог и продразвёрстка - не большевистское изобретение).

Бесправие как в государстве, так и в семье, навязанное невежество, будто бы соответствующее «низкой породе», тяжёлая работа с раннего детства, телесные наказания, невозможность вырваться из-под консервативных и довольно жёстких общинных отношений, бесправие женщин, высокая детская смертность и веками формируемое равнодушие к собственной судьбе, огрубение души вследствие невозможности развития для большинства выше уровня ЦПШ...

И за почти сорок лет после отмены крепостного права мало что изменилось. Апелляция к тому, что столыпинские реформы что-то могли изменить, подготовить эволюцию в социальных отношениях - обычный популизм. Аграрная экономика полуфеодального типа была к этому не способна.

Хлеб, которого не хватало крестьянам шел на экспорт, поскольку за него платили валютой, а на нее можно было покупать товары, которых, в промышленно отсталой России не было. Разговоры о том, что Россия кормила Европу и благоденствовала, мягко говоря, несостоятельны: при исключительном стечении погодных условий и самом высоком для царской России урожае 1913 года Российская Империя вывезла 530 млн. пудов всех зерновых, что составило 6,3\% потребления европейских стран (8,34 млрд. пудов). При этом Россия боролась за свою долю на рынке, по свидетельствам дореволюционных экономистов, только очень низкой ценой, но не качеством. Развитой аграрной культуры тоже не было.

То есть речи не может быть даже о том, что Россия кормила не то что Европу, но и даже пол-Европы.

Но, возможно, доходы от продажи хлеба шли на развитие страны? На улучшение положения народа? Но нет, исследователи отмечают, что на расходы аристократии было потрачено 180 миллионов; 140 миллионов русские дворяне оставили за границей (noblesse oblige: курорты Баден-Бадена, казино, недвижимость в Европе). На модернизацию России «эффективные собственники» потратили одну шестую дохода (58 миллионов руб.) от продажи зерна, выбитого у крестьян. И другие «достижения» правящей «святой» 
царской семьи: $2 \%$ в мировом производстве; 500 тракторов на всю Россию (в основном соха); 1,5 врача на 10 тыс. населения, 263 ребёнка из тысячи умирали; 80\% безграмотного населения; 10 млн. учащихся на всю Россию, то есть 1, 7 на тысячу человек, в вузах обучались 127 тысяч человек.

Стоит ли задавать вопрос о возможностях и желании царского правительства провести быструю индустриализацию с такой системой управления? Ответ достаточно очевиден.

Для сравнения. После Октябрьской революции: повсеместная реализация плана ГОЭЛРО (в 1925 году электрификация уже превзошла уровень 1917 года); за пять лет из аграрной страны Россия превратилась в индустриальную; полная ликвидация безграмотности. К 1947 году число инженеров в СССР превысило аналогичный показатель в США, к 1941 году - 7 тысяч тракторов в год, к 1948 году - атомная промышленность, 1957 год - запуск спутника, 1961 год - первый полёт человека в космос, 1960 год - среднее и высшее образование стали бесплатными, 856 вузов, 5 миллионов студентов (сколько во Франции, ФРГ и Англии, вместе взятых), к 1980 году фундаментальная наука стала одной из наиболее развитых отраслей производства, в ней были заняты один миллион человек.

Традиционное возражение: прогресс на крови. Жизнь - всегда ценность, смерть - всегда трагедия. Но стоит вспомнить, что в Российской империи только из-за повышенной заболеваемости от голода, чрезвычайно слабо развитой медицины и гигиены за год умирало более 250 тыс. человек. За все 33 года правления Сталина в СССР, отягчённого последствиями Гражданской войны, классовыми противоречиями, несколькими войнами и их последствиями было приговорено к расстрелу по максимуму 643 тыс. человек (приведено в исполнение меньше, но возьмём даже эту цифру). Очевидно, что это число перекрывается всего 3-4 годами повышенной смертности в царской России. И это только одна статья пренебрежения «человеческим материалом».

Здесь неплохо бы вспомнить и некоторые другие факты. Опуская подробности жестокости по отношению к крепостным, которая шокировала иностранцев (так, Шарль Массон писал: «Я уже отмечал, как возмутительно в России обращение с людьми. Присутствовать хотя бы при наказаниях, которым часто подвергаются paбbl, и выдержать это без ужаса и негодования можно только в том случае, если чувствительность уже притупилась и сердце окаменело от жестоких зрелищ»), обратимся к реалиям начала XX века. Отношение к народу никак не изменилось. Процитируем приказ министра внутренних дел П. Дурново киевскому генерал-губернатору (по поводу крестьянских волнений): «...немедленно истреблять, силою оружия бунтовщиков, а в случае сопротивления - сжигать их жилища...». И распоряжение тамбовского вице-губернатора полицейскому командованию: «меньше арестовывайте, больше стреляйте...». По отношению к крестьянам в XX веке применялись юридические нормы, которые не действовали для других слоёв населения. Либерал Столыпин таким образом разъяснил позицию царского правительства: «Правительство в целях самозащиты вправе «приостанавливать все 
нормы права». Только по приговорам военно-полевых судов было повешено с августа 1906 по апрель 19071102 бунтовщика.

Ещё один упрек, который достается Советской власти, обобщённо состоит в следующем: «Советская власть подчиняла личность коллективу и интересам государства». Не станем говорить о том, что коллективизм сам по себе - высокая нравственная ценность; коллектив, а не индивид создал цивилизацию. Коллективистские ценности были заимствованы Советским государством и развиты на почве уже существовавших в русском менталитете коллективных образцов. При этом общинный коллективизм дореволюционного образца существенно отличается от советского. Основой крестьянского коллективизма являлось православие, которое после раскола христианства получив духовную независимость и избежав внутриконфессиональных противоречий, сделало упор на коллективность, мистицизм и иконопочитание. Для любителей «духовности» отметим, что православие держалось, в том числе и на репрессивных мерах. В Уголовном кодексе Российской империи 1845 года [1] имелись десятки уголовных статей за преступления против веры с невероятно суровой ответственностью, что довольно плохо вписывается в изначальную религиозность русского народа и концепцию его «духовного единения» с Церковью. Подчинение, смирение, почитание вышестоящего - вот те ценности, на которых держался крестьянский коллективизм. Советская же идеология связывала с коллективизмом иные ценности: альтруизм, товарищество, дружбу, преданность друзьям, социальное равенство.

Что касается государственного давления в плане ценностных ориентаций и соответствующего им поведения, то любое государство, развиваясь, ставит определённые цели перед обществом, вне зависимости от строя. И весь вопрос в том, что это за цели: масштабный проект модернизации и прогресса для общества или индивидуальная свобода открыть частную обувную лавочку/магазин/ресторан и комфортнее жить как предел мечты (что, конечно, неплохо, но масштаб не тот). Ценности и капитализма, и демократии, и социализма не генетически присущи человеку, эта та же система социального и государственного воспитания. И пока существует государство, оно будет участвовать в целеполагании развития общества и в формировании его системы ценностей.

Институциональные изменения после Октября 1917 года запустили процесс личностной трансформации человека, формируя черты нового типа. Сразу отметим, что единого типа «советского человека» не существовало никогда, как и свойственно развивающемуся обществу, идеал менялся в зависимости от общественных потребностей: в 1920-е годы - это революционерразрушитель старого мира («железные» комиссары, «стальные» чекисты); 1930-е годы - созидатель Нового мира («индустриальный человек», «научноорганизованный человек»). Впоследствии востребованным стал человек как часть государственного механизма (часто встречается термин «винтик»); к 1960-м годам - как раз тот тип идеала, о котором мы и говорим - homo soveticus - человек, сочетающий в себе «высокую идейность, широкую 
образованность, моральную чистоту и физическое совершенство», но при этом ориентированный на коллективные и государственные ценности. Собственно, и этот идеал не нов: если мы возьмем труды античных философов и греческий идеал калокагатии, то мы увидим то же самое, как и приоритет общего над частным.

Конечно, вопрос о «человеке советском» стал дискуссионным во многих плоскостях, а точки зрения разнятся до полярных. Так, книга «Советские люди», выпущенная Политиздатом в 1974 г., объявила, что «Советский Союз стал родиной «нового, высшего типа человека разумного - Хомо Советикус».

Естественно, оппоненты черты эти оценивали не столь оптимистично, в диапазоне от «иронично до негативно». Приведём несколько цитат из работ учёных и публицистов, которые позволяют охватить спектр мнений в этом направлении. А. Зиновьев (о нём мы уже сказали): «Взгляните на этого [советского] человека! Он неглуп и образован. Его никто не оболванивал, не запугивал, не развращал. Скорее наоборот, он сам это делал в отнотении других людей, которые, однако, не считают себя оболваненными, запуганными, развращёнными. Советских людей вообще нет надобности подвергать такой обработке, так как они сами способны кого угодно оболванить, запугать, развратить. Это - их натура, и потому им приятно это делать как в отношении себя, так и других». [6].

М. Геллер, находившийся шесть (по другим сведениям семь лет) лет в лагерях, что, конечно, не могло не сказаться на оценке, так же описывает черты, которые присущи всем homo soveticus вследствие «социальной дрессировки», осуществляемой компартией: «Психиатр и психолог Бруно Беттельгейм описал, используя собственный опыт узника Дахау и Бухенвальда, «поведение индивида и массы в экстремальных ситуациях». Его вывод: создание экстремальной ситуачии - арест, избиения, пытки, заключение в лагерь - имеет целью «навязать заключенным детское поведение», ускорить трансформачию взросльх людей в послушных детей. Бруно Беттельгейм видимо не подозревал, что анализируя поведение палачей и жертв в германском концентраиионном лагере, представлял одновременно основные этапь трансформации человека в Советском Союзе». [4]. Ф. Эллис, профессор Лидского университета, дисквалифицированный за расизм, так себе представляет советского человека: «...B результате формируется полный страха и лишённый интеллектуальной инициативности Hото soveticus, который является рупором для партийных идей и лозунгов, это не столько человеческое существо, сколько сосуд, который наполняется и опорожняется по указанию партии» [9].

Нельзя в этой связи не вспомнить и знаменитое исследование бывшего главы партбюро Института конкретных социальных исследований, подвергшегося в 1969 году политической чистке и лишённого звания професcopa, Ю. Левады «Homo Post-sovieticus». Вот примерный набор черт советского человека в его интерпретации: социальное лицемерие, патернализм, подозрительность и изоляционизм, «упрощённый» в своих представлениях 
и запросах человек. Так, исследователь утверждал, что нового человека создано не было, но был создан новый тип приспособленца, готовый принять советскую реальность как безальтернативную данность. [8].

При этом отметим, что само исследование таких эмпирических данных не содержит, оно в целом посвящено адаптации бывших граждан Советского государства к новым условиям и системе, на что и направлен весь круг вопросов. Все остальные элементы (перечисление черт якобы свойственных советскому человеку и советской действительности) представляются аксиомами, хотя таковыми не являются. В целом, согласимся с мнением Е. Габовича, который отмечает, что в исследованиях Левады присутствует желание представить советское общество сложенным из людей определённого «антропологического типа», в противоположность западному обществу, где принято выделять разные типы.

В целом, большинство работ, дающих негативную оценку «советского человека», чрезвычайно похожи по содержанию, отличаясь нюансами и стилистикой. Все вместе они создают определённый узнаваемый образ абстрактного homo soveticus: образ бездушного, запуганного системой, коррумпированного и склонного к доносительству, полного страха и лишённого интеллектуальной инициативности, развращённого, без собственных убеждений «сосуда наполняемого и опорожняемого по указанию партии», склонного к созданию образа врага, к социальному лицемерию, безропотному подчинению, воровству, подозрительности, изоляционизму и пр.

Но когда люди начинают искать подобного среди своего ближайшего окружения подходящего возраста, или обращаются к истории семьи, то такого человека, как правило, не находится: ни деды, ни родители, ни братья и сёстры, ни близкие знакомые такими чертами, оказывается, не отличались.

Да и жизнь не была сплошным маршем в концлагерь/ очередную «стройку века» под советскими знамёнами с портретом Сталина наперевес. Но...это же квинтэссенция человека советского! В чем же дело?

И здесь всегда помогает обращение к конкретным человеческим примерам. И размышления на эту тему зачастую приведут к своей семье, которая, как и любая семья этого столетия, имеет отношение к советскому времени и советскому менталитету.

Говорить о формировании нового типа человека - homo sovieticus, который был бы полностью детищем советской системы, можно, на наш взгляд, начиная с конца 1950-х, в полной мере в 1960-е и 1970-е годы. Общее образование, воспитание, идеология, сложившаяся система социальных лифтов, связей и гарантий, наличие общей истории, культуры, социальных привычек, закреплённых в образе жизни - все эти элементы менталитета «человека советского» формируются с указанного времени. Так что я обращусь к примеру моей матери - Милаевой Веры Ивановны, которая относилась к поколению поздних шестидесятников, людей, родившихся между 1925-1950 годами. Её жизненный путь в той или иной степени для советских людей был обыкновенной историей. 
Родилась Вера уже после войны, в 1947 году, в семье инвалида войны Никитина Ивана Степановича и библиотекаря районной библиотеки Никитиной Екатерины Иосифовны в г. Беднодемьяновске (сейчас г. Спасск). Ст. лейтенант Никитин потерял ногу в боях под Москвой в 1942 году, был комиссо-

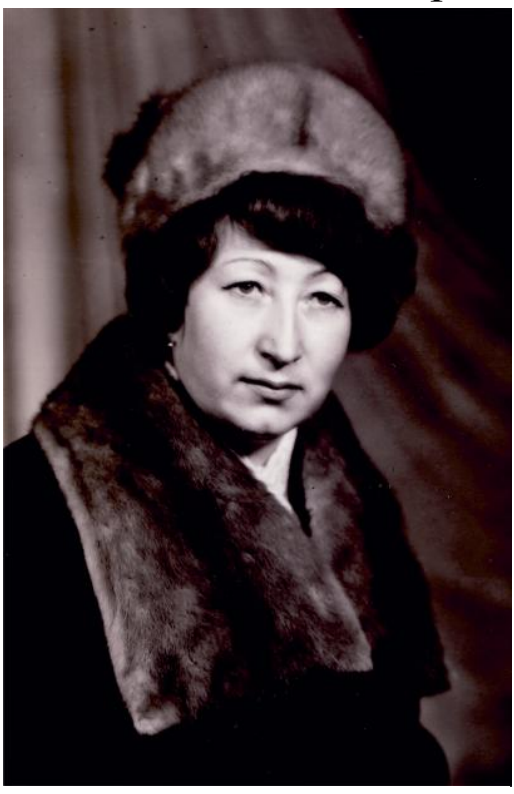

Рис. 1 Милаева Вера Ивановна ван, много позднее был награждён медалью «За оборону Москвы», медалью «За победу над Германией в Великой Отечественной войне 1941-1945 гг». Но как коммунист и человек, имевший среднее специальное образование (техникум), был направлен на организационную работу: сначала в Пензу (дед был коренным пензяком), затем, женившись, перебрался в Беднодемьяновск. В последующее время занимал различные должности: от учителя черчения и директора вечерней школы до директора керамической фабрики. Отмечу, что, несмотря на то, что дед с 22 лет был коммунистом, дом не был увешан портретами Сталина, не цитировались в обязательном порядке труды классиков марксизма-ленинизма и торжественные сталинские речи, и притихающих разговоров не было при упоминании этого имени. Да, висел портрет Ленина, поскольку это был подарок от типографии, в которой работал отец бабушки.

Бабушка, окончив 10 классов в 1941 году, планировала учиться в Пензе и получить специальность агронома, но помешала, как и многим, война. Потом замужество и ...дети, конечно. По меркам того времени семья не была многодетной - было всего трое детей, но стать агрономом Екатерине Иосифовне всё же не пришлось. В отличие от деда, бабушка никогда не была членом коммунистической партии, но и активной агитации, тем более давления со стороны деда не было никогда.

Трудолюбие и уважение к труду воспитывала и семья и школа. Школа во многом создавала первичную систему организации детской жизни, общественных и коллективных отношений, в ходе которых личность ребёнка формируется. Мама всегда вспоминала, что школа для них не была местом, где отсидел уроки - получил задание - выполнил - отчитался - забыл. Нет, она говорила, что именно там все приобретали друзей, с которыми впоследствии общались всю жизнь, навыки, которые нельзя получить только в семье. «Школа для нас не была местом демонстрации индивидуальных достижений или семейного дохода. Все в основном одевались и жили одинаково. Зато мы ценили другое: как ты учишься, какой ты друг, что ты прочитал, кем ты хочешь стать». Много позже, когда на телевидении стало много фильмов про американскую школу, особенно маму удивляли школьные проблемы американских подростков: травля одноклассников, проблема популярности, секс, «ненавижу читать». Она говорила, что, «видимо, у нас было такое несвободное общество, что проявления лимбической системы мозга и инстинкты звероящеров держались под надёжным контролем. 
В то время было модно заводить друзей по переписке заграницей. У меня была подруга из Венгрии (переписывались на русском), из ГДР (переписывались на немецком) и ещё из Вьетнама (переписывались на русском), но и там таких проблем у школьников не было». Слово «ботан» мама вообще не понимала: если, по её словам, и был в то время у нас в школе целенаправленный идеологический элемент, так это культивирование интереса к чтению, книге. И это давало возможность советским детям такого расширения кругозора и развитие образного и логического мышления, какое недостижимо в эпоху клипового мышления и картинок; расширяло круг интересов детей, сельские ребята не были ограничены своим мирком, у них появлялись другие мечты, перспективы и стремления. В чтении же в некотором роде секрет грамотности советских людей - постоянное чтение развивает не только мышление, но и даёт навык и образ грамотной речи.

Мама всегда считала, что ей очень повезло - в их доме была своя библиотека, по тем меркам даже большая: кроме сочинений Ленина, Сталина, философских словарей и некоторых работ Маркса и Энгельса, учебников, книги Толстого, Горького, Зощенко, Аверченко, Загоскина и др. Там же была и Библия прабабушки. Никому читать её не возбранялось, «сосуд наполнялся и опорожнялся» не по «указанию партии», а в зависимости от детских склонностей и интересов. Другое дело, что особого интереса Библия не вызывала (в отличие от греческих мифов). Внеклассное чтение и летнее чтение задавали и вектор детских литературных интересов. Поэтому, по воспоминаниям мамы, они читали не только книги по школьной программе, не только военно-патриотические произведения, модные тогда истории о разведчиках, но и Дюма и Скотта, Буссенара и Сальгари, Сабатини, но в старших классах ей нравилась публицистика - Добролюбов и Чернышевский, статьи Л. Толстого, Белинский.

Ценность научного прогресса, связанного с развитием точных наук и техники, была одним из краеугольных камней социалистической идеологии, поэтому особое внимание уделялось в школе точным наукам. «Да, в истории и литературе была, скорее, схема. Но это для школьной программы. Читать другую литературу, обдумывать, размышлять над ней никто не запрещал. Да и впоследствии я думала, что сверхограничений на какую-то литературу не было. Самиздат, несмотря на полулегальное положение, никем особо не ограничивался, кто хотел, тот и читал Солженицына, Набокова, Бродского, Цветаеву. Да, собственно, в 70-х их не просто читали, а ставили на сцене, в том числе и в полупрофессиональных театрах. Твои тётя и дядя преспокойно репетировали Мандельштама для «Голоса поэта». Ну, то самое: «Мы живём, под собою не чуя страны...» И когда что-то было полутайной был интерес и популярность их была выше, чем потом, когда это чтиво было во всех книжных. Если же автор сетует не на то, что его не читают, а на то, что не признают и не издают официально - это уже совсем другое».

В школе работали кружки юных физиков, кружки усложнённой математики и пр. «И, если я могла получить «двойку» по истории за ответ «буржуазия» на вопрос «Кто был классом-гегемоном и движущий силой 
революции?», то формулы и доказательства помнила даже во сне». Уже тогда проводились всесоюзные олимпиады по физике и математике, чему было положено начало еще до войны академиком И.М. Гельфандом. Эти олимпиады можно считать одним из факторов успеха ядерного и космического советских проектов. В одной из таких олимпиад мама и принимала участие в 1963 году. «Нет, места я никакого не заняла, но уже тогда определилась, что хочу быть инженером и работать в космической отрасли». Но особенно запомнилась встреча с В.М. Брадисом. В рамках блиц-вопросов проверялись не только формульные знания, но и общий уровень осведомленности олимпиадников. И вот маме достаётся вопрос: когда впервые появились таблицы четырёхзначных логарифмов и натуральных тригонометрических величин (таблицы Брадиса)? «Я вполне уверенно ответила, что давно, ещё в прошлом веке. Профессор смотрит и спрашивает: «И что, этот изобретатель тоже был давно, в прошлом веке? Да, - отвечаю, - уже, наверное, умер». Сердито на меня посмотрел и говорит: «И, тем не менее, вот я живой и перед Вами сижу!».

А уж когда она получила первый раз за хорошую учёбу мечту многих советских детей - путёвку в «Артек» - это и гордость, и счастье, новое общение. «Мы в детстве мало куда выезжали с родителями, поэтому представление о людях - это в основном люди нашего городка...Я впервые увидела почти весь Советский Союз. И какие же мы все разные! И как интересно было знакомиться, играть в «Зарницу», решать сложные задачи вместе. Ведь огромный Советский Союз был географической абстракцией для нас в то время. И вот - такая возможность».

Довольно странно слышать об абстрактности советского образования. Школьные знания и знания, полученные в вузе, всегда помогали в жизни. Да советские люди сами делали ремонт и обустраивали жилище: высчитать количество требуемых обоев для оклейки комнаты до сантиметра - не вопрос, посчитать количество штукатурки - пожалуйста, рассчитать места для мебели, которой нет пока в наличии - тоже; количество краски с определённой толщиной покрытия пола - можно. Маму тоже такое утверждение удивляло: «Если речь идёт о знании, например, математики - в том числе, и высшей - то как раз оно было практическим. До того как сначала калькуляторы, затем компьютеры стали массовыми, и стали возможными массовые «численные» решения задач, в инженерной деятельности приходилось действительно применять математические формулы». И это ещё не говоря о том, что эти «абстрактные» знания представляли собой единую систему, на основании которой потом выстраивались уже чисто профессиональные умения.

Или то же, кажущееся сейчас полностью отвлечённым, знание литературы. Это формирование единого культурного пространства, культурных кодов коммуникации, на эту культурную базу можно ссылаться, речь звучит интереснее, язык обогащается.

Ну и, конечно, притча во языцех - профессионально-трудовое воспитание: школьников заставляли работать, хотели скорее сделать из них рабочих. 
Вообще трудно найти общество, которое бы поощряло лень и бездействие. Но ранее труд, особенно физический, рассматривался как тяжёлая обязанность, свойственная представителям низших классов. В Советском Союзе концепция труда и человека труда принципиально меняется: трудовая деятельность рассматривается одновременно как функция созидательная (построение нового мира) и воспитательная (создание нового идеала человека для нового мира), труд становится этической категорией. Трудовое воспитание включало и производственное образование. Чтобы 15-летние юноши и девушки после 9 классов могли работать на производстве, закон обязывал школу обеспечить овладение школьниками профессией во время обучения, а также предусматривал обязательное участие школьников в общественно полезном, производительном труде. Как ни странно, но в Западной Европе и США такая модель практикуется, считается, что молодое поколение становится более ответственным, самостоятельным и независимым. При этом уходившие работать молодые люди впоследствии могли продолжить образование, благодаря созданной системе вечернего и заочного обучения.

Мама, как и большинство советских детей 1960-х, получила по окончании школы и свидетельство о профессиональном образовании с присвоением квалификации «портного по изготовлению лёгкого женского платья 3-й категории». И вот, пожалуйста, можешь учиться дальше или идти работать (нет, не чтобы заработать на обучение в вузе, которое, как известно, было уже бесплатным). Тем более по такой модной теперь специальности почти модельер-дизайнер... Но молодежь шестидесятых не привлекал пошив одежды: техника, спутники, ракеты, космос, романтика дальних странствий, наука - вот куда они стремились.

СССР предоставлял для труда и образования широкие возможности. При этом требовались высококвалифицированные специалисты. А, значит, требовалось получить высшее профессиональное образование. В целом, развитие высшего образования в 1960-70-е годы шло ускоренными темпами. Подготовкой специалистов и проведением исследований в вузах СССР в 1972 г. было занято 366,2 тыс. научно-педагогических работников [5].

И даже районная школа предоставляла своим выпускникам такие возможности. «Из нашей районной школы вышли учёные и художники, литераторы, врачи, учителя, инженеры, среди которых оказалась и я» - так мама рассказывала на вечере, посвящённом 50-летию их школы, куда были приглашены выпускники прежних лет. «Увы, знаменитый Физтех в первый год поступления оказался мне не по зубам, я вернулась домой и, в ожидании года следующих вступительных испытаний, устроилась работать на швейную фабрику, поскольку ещё в школе получила рабочую квалификацию».

В следующем году Вера уже поступила в Пензенский политехнический институт на механический факультет. Через два года в связи с устройством на работу в Пензенский научно-исследовательский электротехнический институт перевелась на вечернее отделение. Принята была на работу техником, затем через три года стала старшим техником. «Много позже, когда я сама уже принимала студентов на практику, - вспоминала мама, - 
я оценила разницу в отношении: нас, ещё даже не специалистов, не просто формально принимали и подписывали бумаги, но помогали и обучали. Отношение было внимательным и доброжелательным, была заинтересованность. Возможно потому, что практиканты рассматривались как потенциальные сотрудники, почти все потом приходили устраиваться в институт работать, если проходили отбор. Сейчас приходят немногие (режимное предприятие не подходит современной молодёжи), молодые люди чаще всего с целью не служить в армии, так как наш институт даёт такую возможность»)».

НИИ-3 (теперь ПНИЭИ) развивал ресурсы в области разработки и промышленного изготовления новых видов техники защиты информации специального назначения. В том числе и системы космической связи. Работать на таком предприятии, несмотря на строгий режим, уже тогда среди будущих молодых инженеров было престижно, давало возможности творческого профессионального развития. Но это было связано и с высокой степенью ответственности за результаты труда, тем более работа была связана с доступом к определённым формам секретности.

Это же делало работу зачастую непредсказуемой с точки зрения временных затрат. Выходные? Отпуск? Праздники? В любой момент могут вызвать на испытательный участок, я оставалась дома. Но это не трагедия, а труд. По воспоминаниям коллег, Вера Ивановна всегда отличалась организаторскими способностями и лидерскими качествами: через два года после окончания вуза была назначена начальником бюро, впоследствии начальником конструкторского и технологического бюро. Вела и общественную деятельность, хотя в партии никогда не состояла, много лет была профоргом крупного отдела. При внедрении новых стандартов качества и системы менеджмента качества в производство руководила отделом технического контроля. При расширении отдела, создании на предприятии службы технического контроля качества, разработки и внедрения новых международных стандартов ISO, стала заместителем начальника службы технического контроля качества, проработав на предприятии почти 40 лет.

За такое время, кажется, любая работа становится рутиной, но если это просто работа. «Мы не говорили работа, что похоже на рабство. Мы относились к работе как к труду на благо общества, для будущего развития. Во всяком случае, я так считала, ну, или нас так учили. И особенно в молодости рутинность снимается профессиональным творчеством. Для инженера творчество - это рационализаторство и изобретательство». В сведениях о награждениях в трудовой книжке Веры Ивановны есть награды и премии не только за общественную деятельность, многолетний добросовестный труд, но и за рационализаторские предложения.

Научное творчество вообще было чрезвычайно распространено в СССР, при этом как среди профессионалов, так и младшего поколения, школьников. Мама, будучи членом комиссии по отбору рационализаторских предложений и научного творчества школьников (подшефной для ПНИЭИ было школа № 4) вспоминала, что «эти ребята мыслят совсем по-другому, чем мы 
ранее, более технично, даже профессионально для школьников». Прогресс советской школы в 1960-70-х годах в точных науках очевиден. Тем более успехи впечатляют, если вспомнить, что их добилось за 30 лет бывшее полуграмотное сельское население, привыкшее к крестьянскому быту, которое не просто научилось использовать сложные машины, но и производить их, работать не в привычной общине, а в непривычно сложных организациях, социальных институтах.

Сформированный целостный взгляд на мир поколений советских людей, декларируемая рациональная легитимность системы, основанная на идеях прогресса и надежде на лучшее будущее, позволяла переносить не всегда комфортные жизненные условия, но развивать науку, производство и трудиться. Впрочем, жертвы малым во имя великой цели, жертвы индивидуальным во имя общего блага, черта не только советского человека и общества. Так, Лотман, анализируя движение декабристов, приходил к выводу, что «...Нейтральные или незначительные действия не существовали. Сама возможность их существования отрицалась.... Для декабристов священной была не праздность...существовал культ братства, основывающегося на единстве духовных идеалов, и восхваление дружбы». Практически ранняя советская идеология, которая, как в идим, вполне вписывалась в картину мира более раннего периода. Похожие черты можно встретить и у героев Чернышевского.

С 1980-х картина начала меняться. Мама отмечала, что до 1980-х годов труд инженера был более свободным и творческим, восприятие жизни обществом более романтическим, была героизация обычного труда. С 1980-х пришла стандартизация. «Приходящие студенты стали слишком узкими, как будто их затачивали на выполнение одной операции, по схеме, по алгоритму. Они демонстрируют навыки квалифицированных рабочих, но не инженерное мышление». Собственно, то же самое отмечают исследователи ИТР в СССР начало упадка массового инженерного образования - это середина 1980-х годов [5]. А в современной России по данным науковедов инновационная активность более чем в 10 раз ниже, чем в Советском Союзе до начала реформ.

Проработав почти 40 лет в ПНИЭИ, Вера Ивановна стала ветераном труда, была награждена значком «Почётный радист» за активное участие в деятельности и развитии радио и телевидения, за достижения в области науки, техники, производства, эксплуатации, организации телерадиовещания и многолетний добросовестный труд. Результатами своего труда весь коллектив гордился. Когда к нам приходили гости, то зачастую велись именно профессиональные разговоры, даже я, будучи ребёнком, помню названия их проектов «Шпага» и «Черемша» (надеюсь, что это уже не секретно) и даже перипетии испытаний.

И вот ещё такой эпизод. ПНИЭИ осуществлял подготовку систем связи, в том числе космической. И эти системы обеспечивали работу связи на орбитальной станции «Мир», когда она была затоплена в 2001 году. Мама созванивалась с коллегами, они все делились новостью, не радостной, 
конечно. «Ну что ж, последнее, что работало на станции - была связь», подвела мама итог.

Разрушенные заводы, НИИ, закрытые детские сады, оптимизированные школы и больницы, - всё, что создал homo soveticus, на глазах последнего поколения разрушалось: совершенно не удивительно, что к такому государству они адаптироваться не могли и не хотели. И не в силу неспособности и склонности к патернализму. А в силу крайней несхожести менталитета, ценностей, идеалов. Но вот здесь на руку новому государству сыграла роль преданность советских людей труду, профессии, коллективу: вряд ли даже у «конструкторов изменений» было бы желание, чтобы все вдруг стали адаптироваться через предлагаемые «широкие возможности» (торговля, сервис и пр.). Благодаря этим «не адаптируемым» homo soveticus сохранились отрасли наукоёмкой промышленности и высококвалифицированный кадровый состав.

С 1990-х годов, как и многие подобные предприятия, ПНИЭИ переживал период номенклатурной приватизации. У Геллера читаем: «Травматические шоки формируют советского человека: история СССР - серия мучительно болезненных ударов по бытию и сознанию». Не знаю, как ударили по сознанию бесплатная медицина, образование, социальные гарантии, защита материнства и детства, отсутствие безработицы... Но вот «травматические шоки» 1990-х ударили сильно. Более всего маму радовало в той ситуации, «хотя бы высшее образование бесплатное успела дать». Высшее образование, потом и аспирантуру я успела получить бесплатно, как и многие дети заката Советского Союза. Но уже не стараниями государства, а усилиями родителей. Дать хорошее образование - и сейчас главный императив российских родителей, это считается лучшим способом позаботиться о будущем детей. Вот только смысла в высшем образовании всё меньше: существующая номинальная профориентация не способна определить подходящую профессию, а ЕГЭ позволяет подавать документы на несколько специальностей с иногда удивительным набором вариантов (например: физика, социальная работа, менеджмент; психология, математика, юриспруденция). О какой профессиональной ориентации и сознательном выборе может идти речь? «Одно радует: выпускники всё равно не идут работать по специальности в большинстве случаев. Это и по нашему институту и практикантам видно. Но, думаю везде такая ситуация», - констатировала мама. Да, по результатам опросов 60\% выпускников не пойдут работать, реализуя знания, полученные в вузе. Глядя на предлагаемые вакансии, несложно предположить почему.

Но образование для родителей поколения homo soveticus значительно отличается от современных представлений. Современные родители шире участвуют в решении организационных и материальных вопросов в школе, но меньше внимания по различным причинам могут уделять развитию детей (я не говорю о том, чтобы отдать дитятко в школу раннего развития). Музеи, театры, кино, совместное чтение, лыжи и коньки, экскурсионные поездки по городам, шахматы и музыка, живопись - всё это есть и теперь. Нам прививали это «лишённые интеллектуальной инициативы» родители 
типа homo soveticus, при этом они сами нам всё рассказывали, показывали, объясняли. В одной из наших поездок (в Волгоград) мама сама мне проводила экскурсию по Мамаеву кургану; в Третьяковке мы не брали экскурсоводов; мы обсуждали спектакли, обучались декламации. Ну, наверное, это были те самые «бесполезные абстрактные знания». Тогда как теперь чаще детей водят в торговые центры, на вопросы - «посмотри в интернете». Прекрасно, что современные дети сильны в технике, но развитие происходит в семье и социуме; как и уважение к родителям формируется с детства и их знания играют в этом не последнюю роль.

Как и общение с коллегами и друзьями. Особенно при сравнении homo soveticus выигрывает в плане дружеской взаимопомощи. Переезды, ремонты, построить дом на даче, помочь перевезти родителей - всегда был коллектив. Да, коллектив становился семьёй, тёплые дружеские взаимоотношения - нормой, участие и помощь, а не пресловутый интерес к жизни соседей. В обществе тотальной подозрительности и процветающего доносительства вряд ли возможны открытые и частые приёмы гостей, свободные разговоры за столом, не о скидках в соседнем супермаркете и новой мебели, и «как погасить кредит и оплатить долги за коммуналку», кому дать взятку, или о величии вождей.

Мама относилась к поколению поздних шестидесятников, а тогда был культ науки и романтизации открытий и путешествий. У нас висели портреты учёных, поэтов и писателей: Ландау, Есенина, Маяковского. Гостями обсуждались путешествия, литература, театр. Мама вспоминала, что раньше они читали стихи Рождественского и Евтушенко, слушали Высоцкого, хотя он и не был официально признан. Довольно странен вывод об изоляционизме советского человека - напротив, интернационализм, мир без границ, кумиры поколения - Хэмингуэй и Ремарк. Конечно же, чтение и тяга к образованию. Да, у большинства советских людей не было возможности посмотреть мир (впрочем, для нашей семьи это не имело значения - мама была невыездной из-за режима предприятия), но по СССР они ездили довольно часто, а это всётаки 1/6 часть суши. И из поездок привозили впечатления и знания: архитектура, история, атмосфера общества, красота мест. То же самое абстрактное чтение давало возможность знать, куда ты едешь и что хочешь увидеть. Верхом мещанства звучат для меня до сих пор рассказы о «плохом сервисе» и «шведском столе» как главных впечатлениях от «распахнутых границ».

И всегда много книг, даже в 1990-е годы, когда по шесть месяцев не платили зарплату, мама покупала букинистические собрания сочинений Золя, Достоевского, Вересаева, В. Соловьева, Толстого, Мамина-Сибиряка, Цвейга, Генри...Мне сложно вспомнить маму за просмотром бесконечных сериалов «про бандитов и любовь». Но я с благодарностью вспоминаю совместные литературные вечера с чтением вслух, первые уроки стихотворной декламации - тоже мама.

Возвращаясь к 1990-м, можно вспомнить еще об одной черте homo soveticus - безропотному подчинению и безоговорочной поддержке властных решений. Будучи много лет активистом профсоюза ПНИЭИ, получив 
наградную памятную медаль «100 лет профсоюзам России», вручаемую членам профессиональных союзов, которые отличились в областях, касающихся защиты прав трудящихся, усиления правопорядка, общественной стабильности, мама в 1990-е годы впервые, по собственному признанию, столкнулась с таким уровнем неуважения к правам и требованиям трудящихся. «С 26 лет мне приходилось отвечать за людей, работавших под моим руководством. Но никогда не приходилось отстаивать людей, которым грозит увольнение, поскольку «ставок на всех не хватает, а так, хоть у когото будет зарплата». «Уходя на пенсию, я годилась тем, что никого не уволила. Да, не все люди одинаково хорошо работают, но их судьба на твоей совести. Я видела разные примеры... И лучше оставить человека и дать ему шанс, чем потом собирать на благотворительность нищим и подавать бомжам. Уважение к человеку важнее эффективности». Вот так рассуждали homo soveticus - «винтики» в молохе Советской власти.

В 1990-х годах известная ситуация повлекла за собой локауты, затем разорение многих бывших государственных предприятий, безработицу. «В целом мы были более независимы от места работы. Можно было сниматься с места, переходить на другое предприятие, переезжать в другой город. Квалифицированные кадры всегда были нужны. Их старались выращивать и держались за них. Не знаю насчёт уравниловки, но премировали за лучшую работу всегда, жилье, бесплатные путёвки, туристические путёвки, дома отдыха. Дачные участки - тоже бесплатно. А про образование и медицину - все и так знают. Зато теперь есть собственность. Правда, для большинства это квартира в ипотеке на полжизни, так что собственность пополам с банком».

Как мама вспоминала, ей не раз за время работы приходилось иметь дело с конфликтами и недовольством рабочих (испытательные участки, дочерние предприятия, опытные станции - у советских НИИ была широкая база). В основном они касались поставок оборудования, браков, условий труда, компенсаций и прочее. «Но это были производственные вопросы. Узнавая требования рабочих, мы шли к директору, ситуация так или иначе разрешалась. Требования рабочих вообще нельзя было оставить без внимания - встанет производство». Несложно себе представить в современной России судьбу рабочих, предъявляющих «требования хозяину». Рынок труда близок к колониальному, а для квалифицированных кадров возможностей трудоустройства всё меньше.

Поскольку предприятие в результате номенклатурной приватизации становилось ОАО, страдали, прежде всего, рабочие кадры. «И что же они (руководство) предлагают: уволить часть (именно уволить, а не сократить, чтобы не выплачивать компенсации) рабочих и служащих, тогда материальное положение остальных улучшится. То есть как это - жертвовать людьми?» И мама всегда как парламентёр ходила на приёмы к руководству, отстаивая членов коллектива и добиваясь отмены решений об увольнении: «Это их обязанность обеспечить людей рабочими местами, если уж взяли предприятие в собственность». Никакого страха вышестоящего руководства, 
о котором так любят писать в разного уровня исследованиях о советских людях, у Веры Ивановны не было, как, подозреваю, и у большинства.

В СССР отношения между управленцами и профессионалами складывались, как правило, менее напряжённо, чем в капиталистических странах. При капитализме инженеры и управленцы никогда не могли утвердить себя в статусе профессионала, потому что были слишком зависимы от товарного рынка, экономических циклов и меняющихся управленческих стратегий [7]. При социализме позиция управленца зависела от выполнения плана, а его автономия ограничивалась, с одной стороны, министерством, с другой, партийным аппаратом. В официальной советской классификации управленцы включались в состав интеллигенции, и это не вызывало у них возражений. Таким образом, они все были членами коллектива, а не «элитой», «хозяевами» и «простыми работниками». Мама вообее удивлялась - как просто в словарный обиход на постсоветском пространстве вошло слово «хозяин»: «70 лет советской власти, а он всё равно говорит «Хозяин». В нашу бытность вряд ли бы кто-то такое сказал». Да, стоит отметить это введение в языковой дискурс СМИ слов «элита» и «простой народ»: через менее чем 30 лет после падения Советского Союза это стало уже нормой. Вот это и называется социальной дрессировкой и массовой пропагандой.

Групповое сознание начало формироваться в среде бюрократии и специалистов, занятых в производстве, только в период реформ, начиная с конца 1980-х годов. Специалисты руководящего звена, а затем «эффективные собственники» обанкротившихся предприятий, оставшиеся без господдержки на диком рынке, где их технологии не были востребованы, начали с диверсификации производств и увольнения кадров. С аксиомы «требования нельзя игнорировать» перешли к «требования игнорировать можно».

И здесь вызывает сомнение утверждение, что массовые протесты рабочих были организованы номенклатурной верхушкой в ходе борьбы со свободной приватизацией независимых конкурентов. Во всяком случае, в пикете при Правительстве Пензенской области в поддержку рабочих и инженеров НИИ с требованием выплат за труд стоял коммунист тогда глава профсоюза сотрудников ПНИЭИ (1997-98 годы). В отличие от капиталистических стран, общественное сознание в СССР не имело внутренней структуры, определяемой социальной принадлежностью, поэтому протестовали как бы «за права всех». Это особенно ярко проявилось на ранних этапах переходного периода, когда между слоями не было сколько-нибудь серьёзных различий по ключевым политическим проблемам, связанным с созданием рыночной экономики. К примеру, не наблюдалось серьёзных различий между классами в отношении к приватизации и государственной собственности.

Ещё одной особенностью было то, что в СССР все социальные группы имели очень мало опыта в отстаивании своих интересов, особенно экономических. Однако, на этом фоне рабочие и специалисты показали себя несколько более способными к действию, чем другие группы. Так, была собрана группа для переговоров с правительством области 
по вопросу материального положения работающих. Мама в неё входила. «В здание администрации нас впустили как врагов. Разместили в зале, но представителей правительства не было. Мы ждали, ничего не происходило. Потом прошёл слух, что заложена бомба, и часть присутств ующих стали в панике покидать здание. Мы пытались людей остановить, говоря, что это провокация. Но нас не слушали. В результате нас осталось немного, проводили к заднему крыльцу, вышла представитель правительства и пообещала, что вопрос будет решаться. Никогда за годы работы так явно требования рабочих и специалистов не игнорировали. Свобода и демократия», - рассказывала впоследствии мама.

Но девиз поколения всё же был «бороться и искать», поэтому попытки переговоров и пикетов продолжались. «Забитые» и «безгранично поддерживающие власть» бывшие советские люди, как и привыкли, требовали от государства соблюдения обязательств, платы за труд, причём желали разговаривать на равных. «Да «крутиться» и «выживать» мы не были научены, только жить и трудиться», - говорила мама. Вообще, когда я захотела стать историком, мама удивилась, спор физиков и лириков для неё был решен однозначно - «физики в почете», в нашей семье не было гуманитариев. А впоследствии, когда мы разговаривали, мама отметила, что «наше время, это было особое такое время, когда прошлого уже и нет, да оно и неважно, есть пара важных моментов в истории, но вот будущее есть, и его можно строить самим - и что-то обязательно получится, есть вектор развития и куда стремиться; а прошлое, ну что, прошло...Вот на этом нас в 91 году и поймали, когда изменилась сама история. Прогрессом и техникой нельзя заменить память. Ну и ещё, может быть, то, что мы не видели социальной деградации: мы смотрели на наших дедов - стало лучше, отцов - ситуация менялась к лучшему, на протяжении нашей жизни был заметен прогресс, я говорю и о потреблении. Невозможно было поверить в такой упадок. Ведь вся страна продолжала работать, но...». Коллективизм уступил место индивидуализации труда, затем атомизации общества.

Да, советский человек был способен переносить бытовые неудобства, ограничение потребления, отсутствие ста сортов колбасы. Но многие общества и до советского пришли к выводу, что потребление - это не обеспечение прогресса, не путь к раю. Но вот чего советские люди общества равных не признавали и не понимали - это разделения на элиту и простой народ, пренебрежительное отношение к человеку. И это достоинство, и осознание себя личностью, вопрос «кто ты?» вместо «сколько ты стоишь?» - тоже черты homo soveticus. «Союз часто упрекают, - рассуждала мама, - в давлении государства и общества на человека, но обществу подчиняются при любом государстве, не из страха, а из уважения к человеческой идее. Собственно, сама жизнь человека возможна только в обществе. Пример маугли всем известен». Для сравнения: «общество требует, чтобы мы стали его слугами, оставив в стороне свои собственные интересы. Нам приходится приносить разные жертвы и мириться с разными неудобствами, чтобы общественная жизнь была возможной. Однако обычно мы миримся с этой необходимостью 
не потому, что подчиняемся силе, а потому, что испытываем чувство глубокого уважения». К такому выводу приходит Э. Дюркгейм, которого трудно упрекнуть в приверженности марксизму.

Впоследствии в 2000-е годы, уже выйдя на пенсию, мама к общественной жизни интерес не утратила, как и к политическим событиям. Вот такой эпизод: «Снежная революция» 2012 года, спровоцированная результатами очевидных фальсификаций выборов депутатов Государственной Думы и с аналогичной повесткой. Мама принимала участие в митинге в Пензе у кинотеатра «Родина». «Вообще всегда надо вести диалог, нельзя позволять на себя давить, надо предельно ясно объяснять свою позицию. И если права нарушаются - их отстаивать. Россия считает себя социальным государством - так будьте добры к ответу». Митинг проходил в сильный мороз, более двух часов. «Что особенного могу отметить: постоянно присматривали за нами не только обязательные органы правопорядка, но постепенно народ пытались уводить какие-то подозрительные люди. Говорили, что это ФСБшники. Возможно. Даже в 90-х такого не было».

Проработав после ухода на официальную пенсию ещё семь лет, мама решила всё же уйти. И не только по семейным обстоятельствам, и не по состоянию здоровья, а потому что «эта новая среда для нас, бывших, стала слишком тяжёлой, другая атмосфера. Наверное, нужны другие люди. Но тем лучше - попробуем пожить для себя». «Для себя» у homo soveticus получалось хуже, их личность формировалась с более широкими запросами, чем узкий круг домашних интересов. «Хорошо, что я в отличие от некоторых могу позволить себе поездки, театры и музеи, нечасто, но всё же. Ну и почитать есть что - не зря же у букинистов скупала что-то и не успела прочитать. Тем более у нас, пожилых, частая бессонница. Вот полностью согласна с Чеховым: не спать ночью - значит, каждую минуту сознавать себя ненормальным, а потому я с нетерпением жду утра и дня, когда я имею право не спать». Особенно долго мама читала Достоевского, но с присущим советскому инженеру педантизмом просветилась на все 17 томов и поделилась: «Наверное, неплохо, что это были не наши книги, не моего поколения. Их можно читать, рефлексируя на пенсии, но жить, трудиться, стремиться к созиданию и верить в будущее они вряд ли помогли бы. В нашей жизни было много действия, движения. Когда мы остановились - наступил крах. С другой стороны, нашему поколению трудно было вообразить такой масштаб социального зла».

Наверное, те, кто общается с людьми старших поколений, могут добавить и другие черты к портрету и обыкновенной истории homo soveticus. Но и сейчас для многих понятно, что это не история непрерывных мучений в тисках социального эксперимента над человеком под названием Советский Союз, а обыкновенная человеческая жизнь в первом в истории социалистическом государстве, прогресс которого был очевиден даже в очень ограниченных хронологических рамках. В целом отметим, что западный публицистический дискурс, апеллирующий к негативным чертам homo soveticus, базируется на изначальной аксиоме об аморальности и искус- 
ственном навязывании идеи социализма как таковой в принципе (см. напр., А. Юрчак), что автоматически делает «плохим» все от этого производные, в том числе и членов этого общества.

Homo soveticus - это не единый антропологический тип, а определённый идеал, набор значимых для развития общества и человека нравственных качеств, которые не были изобретением большевиков, но которые сделали его своей целью в социальном и ментальном пространстве. В этом типе просматриваются идеальные качества homo sapiens, формируемые в этических системах античности, христианского средневековья, классической немецкой и постклассической философии, в русской литературе, в социальных теориях XX века. Но идеал и человек - вещи несовместимые, слишком человек индивидуален. Поэтому поляризация мнений по вопросу «советский Человек» или «совок» тоже зависит от индивидуального восприятия: ну, что же, кто-то видит лужу, а кто-то видит в луже солнце.

\section{Источники и литература:}

1. Антиправославная ответственность в Российской империи [Электронный ресурс]. http://www.ruskolan.com/liter/kritika/prest.htm(Дата обращения 10.08.17)/

2. Блок А. «Интеллигенция и Революция». [Электронный ресурс]. http://az.lib.ru/b/blok_a_a/text_1918_intelligentzia_i_revolutzia.shtml (Дата обращения 15.08.17)/

3. Булгаков С. «На пиру богов» [Электронный ресурс]. http://az.lib.ru/b/bulgakow_s_n/text_1918_na_piru_bogov.shtml(Дата обращения 15.08.17)/

4. Геллер М. Машина и винтики. История формирования советского человека. - М.: МИК, 1994/

5. Гусарова М.Н. Исторический опыт формирования инженерно-технической интеллигенции в советской высшей технической школе в 1950-1980-е гг.// «Научные ведомости» БелГУ. Серия История. Политология. Экономика. Информатика. 2010. № 1 (72). Выпуск 13.

6. Зиновьев А.А. Гомо советикус. - М.: Центрополиграф, 2000.

7. Кивинен М. Прогресс и хаос: социологический анализ прошлого и будущего России. [Электронный pecypc]. -http://texts.news/pervoistochniki-sotsiologii-knigi/nachalnikiinjeneryi-43914.html. (Дата обращения 11.08.17).

8. Левада Ю.А. Homo Post-Soveticus. Человек приспособленный // Общественные науки и современность. - 2006. - №6.

9. Ellis $F$. Multiculturalism and Marxism. // American Renaissance, November 1999 [Электронный ресурс]. -https://www.amren.com/news/2016/09/multiculturalism-and-marxism/ (Дата обращения 15.08.17).

\section{Referenses}

1. Antipravoslavnaya otvetstvennost' v Rossijskoj imperii [EHlektronnyj resurs]. http://www.ruskolan.com/liter/kritika/prest.htm(Data obrashheniya 10.08.17)

2. Blok A. «Intelligentsiya i Revolyutsiya». [EHlektronnyj resurs]. http://az.lib.ru/b/blok_a_a/text_1918_intelligentzia_i_revolutzia.shtml (Data obrashheniya 15.08.17).

3. Bulgakov S. «Na piru bogov» [EHlektronnyj resurs]. http://az.lib.ru/b/bulgakow_s_n/text_1918_na_piru_bogov.shtml(Data obrashheniya 15.08.17).

4. Geller M. «Mashina i vintiki. Istoriya formirovaniya sovetskogo cheloveka». M.: MIK, 1994. 
5. Gusarova M.N. Istoricheskij opyt formirovaniya inzhenerno-tekhnicheskoj intelligentsii v sovetskoj vysshej tekhnicheskoj shkole v 1950-1980-e gg.// «Nauchnye vedomosti» BelGU. Seriya Istoriya. Politologiya. EHkonomika. Informatika. 2010. № 1 (72). Vypusk 13.

6. Zinov'ev A.A. Gomo sovetikus. M.: TSentropoligraf, 2000.

7. Kivinen M. Progress i khaos: sotsiologicheskij analiz proshlogo i budushhego Rossii. [EHlektronnyj resurs]. $\quad-$ http://texts.news/pervoistochniki-sotsiologii-knigi/nachalnikiinjeneryi-43914.html. (Data obrashheniya 11.08.17).

8. Levada YU.A. Homo Post-Soveticus. CHelovek prisposoblennyj // «Obshhestvennye nauki i sovremennost'. - 2006. - №6.

9. Ellis F. Multiculturalism and Marxism. // American Renaissance, November 1999 [EHlektronnyj resurs]. -https://www.amren.com/news/2016/09/multiculturalism-and-marxism/ (Data obrashheniya 15.08.17). 